\title{
THE CULTURAL CONTEXT OF SEX CENSORSHIP
}

\author{
ERIc LarrabeE*
}

I

In the United States today, no less than in other times and places, the subject of sex is charged with anxiety. In merely raising it, the writer must court suspicion -and consciously, for taboos surround him; immoderate interest would alert, though for different reasons, both the popular and professional mind. Sexual restrictions, moreover, have this logic on their side: while customs vary, the maintenance of emotional tension between male and female-hence, of society's biological vigor-is characteristically associated with some form of social "censorship." 1 The "natural" state of freedom from sexual inhibition is far more likely to be a fantasy of the sophisticated. ${ }^{2}$ Indeed, the rational background of restraint may be better understood by the primitive than by the modern mind. A young West African writer, for example, has explained with awareness and regret why his tribesmen surround with mystery the initiation ceremony of pre-adolescent males: ${ }^{3}$

Not only do they keep women and children in a state of uncertainty and terror, they also warn them to keep the doors of the huts firmly barred. . . . It is obvious that if the secret were to be given away, the ceremony would lose much of its power ... [N]othing would remain of the trial by fear, that occasion when every boy has the opportunity to overcome his ... own baser nature. ... But, at the moment of writing this, does any part of the rite still survive? The secret. ... Do we still have secrets?

Where sex is concerned, the imposition of partial curbs serves a double purpose: to stimulate and to hold back-never too much of either. A counterpoise to individual desires may also measure their intensity, in such an interlocked fashion as to become virtually a condition of their being. This is partly what the would-be censor means when he says that there has always been "censorship," or that the social structure depends on preserving it. In that sense, we all "censor," internally, our own

- Assaciate Editor, Harper's Magazine; Member-at-large, American Council of Learned Societics; Associate in the Columbia University Seminar on Amercian Civilization. Co-author (with Eugene Staley, Ed., el al.), CReating an Industrial Civizization (1952); author, Morality and Obscenity, in Freedom of Book Selection 23 (Proceedings of the Second Conference on Intellectual Freedom of the American Library Association 1954), on which this paper is, in part, based.

${ }^{1}$ E.g., in March 1955, an Australian patrol in New Guinea came upon a tribe of twenty thousand Papuans who had never before seen white-skinned humans. "The women and men live in houses built on the tops of tree stumps, with separate entrances. ... The men's and women's sections are divided by a central wall." N. Y. Herald Tribune, April 1, 1955, p. 3, col. 3 .

2 "There is no such thing as completely frce sexuality in any society, and if there were, as the anthropologist Malinowski makes clear, no culture at all would be possible." Ferdinand Lundnerg and Marynia Farnham, Modern Woman: The Lost Sex 253 (1947). Cf. Bronislaw Malinowski, Magic, ScienCE, AND RELigion 24 (1948). "Contrary to what one vould expect, in savagery sexual cults play an insignificant role." Ibid.

${ }^{3}$ Camara Laye, The Dark Child I08-09 (1954). 
actions and those of others whom we influence. We define in our heads, as a matter of course, the range between what our contemporaries will and will not tolerate. We play between these definitions, stretching them now one way, now another. We live in a state of permanent conflict between our daring and our decency; and, though few go out of their way to say as much, few would have it otherwise.

Yet, censorship, as we commonly know it, differs sharply from this internalized mechanism for enforcing communal assumptions. Of all forms of sex censorship, that of the individual psyche-which sees to it that some things simply cannot be said, even to oneself-is undoubtedly the most effective. It is truly effective, however, only for those tradition-bound societies in which sexual inhibitions are more or less uniformly shared. The modern world, where more than one set of assumptions exist about what is and is not to be allowed, can make sex censorship of literature and the arts a subject of heated dispute. Censorship as an issue, in other words, is almost by definition a by-product of class rivalry. It arises along the shared boundaries between two or more antagonistic schools of thought; and in societies like our own, where law has replaced the rule of universally accepted custom, it is inevitably (though not always successfully) dealt with by law.

Some forms of sexual behavior the law forbids outright: rape, "statutory" rape, incest, sodomy, prostitution, lewds acts with children, adultery, fornication, abduction, and miscegenation-all of which may be defined in terms of a concrete act. ${ }^{4}$ Sex censorship arises, however, not from what is done-at least, not hitherto-but from what is said, written, seen, heard, thought, or felt. The prohibited area in word or image is conveniently characterized by the terms "obscene" or "obscenity," and it falls under the "law" of obscenity-that is to say, an accumulation of statutes and precedent which reflect, but do not necessarily reveal, prevailing definitions of the sexually forbidden. The law underlines the vague sanctions of community disapproval with a tangible threat. It establishes certain minima of censorship, and maxima of license, and, therefore, the limits of acceptable variation in erotic tone. But it suffers severe criticism, even as law, both from its lack of grounding in the material or exact and from its exposed position between rival conceptions of the sexual and social-not to mention the esthetic-good.

Difficulties begin with the idea of "obscenity" itself. Not all that is obscene has to do with sex (e.g., scatology), nor is everything sexually prohibited (e.g., contraception) necessarily obscene. Typically, the word carries one or more of at least three distinct meanings: as (I) something which contravenes accepted standards of propriety, (2) something which tends to corrupt, and (3) something which provokes erotic thoughts or desires. The second and third are often thought to subsume the first, though not the other way around (as one Hemingway character might say to another, "I obscenity in the milk of thy mother's obscenity," without passion

there is considerable variation, however, between one state and the next, both in the acts punished and the severity of punishment. For a tabulation, see Isabel Drummond, The Sex Paradox 345-62 (1953). 
of any kind ${ }^{5}$ ). The first is a common, if ill-defined, phenomenon, including the venerable four-letter Anglo-Saxon monosyllables as well as most of the improper anecdotes that are at any time considered proper to tell. ${ }^{6}$ The second and third have sometimes been regarded as identical, not only by censors, but by courts, as though the fact of sex were in fact obscene. ${ }^{7}$ Even when examined from a purely legal view, the law of obscenity is so hazy and illogical that it tends to disintegrate-to lead inevitably to a conclusion that "[ $\mathrm{n}] \mathrm{o}$ one seems to know what obscenity is."

In the forty-seven states where statutes relating to obscenity exist, all but six define it "by adding one or more of the following words: disgusting, filthy, indecent, immoral, improper, impure, lascivious, lewd, licentious, and vulgar." These words have no objective meaning. ${ }^{10}$ Dictionaries often define them circularly (as the young and curious are frustrated to discover), in terms of one another. ${ }^{11}$ They partake of reality only through shared judgments and largely through assumed standards of sexual behavior or assumed theories of social cause-and-effect. Even in the rare instances where a modern court has held obscenity to be a fact, determinable on examination by a judge or jury, the "true test" of this determination has been found in speculative social psychology-"whether the tendency of the matter charged as obscenity is to deprave and corrupt those whose minds are open to such immoral influences ..."the notorious Hicklin rule. ${ }^{12}$

To the extent that the law of obscenity is the sum of the cases tried under it, the law deals with only a limited part of the relationship between sex censorship and the arts. Censorship may be highly effective, through coercion or consent, and yet be extralegal if not illegal. ${ }^{13}$ The study of the law, case by case, tends to reduce the

${ }^{5}$ E.g., "Go to the unprintable,' Agustín said, 'and unprint thyself. . . ." ERnEsr HeMlngwar, For Whom the Bell Tolls 40 (Blakiston ed. 1940).

"The Reader's Digest, demonstrating its uncanny ability to produce exactly what our people want in the way of reading matter, began to print little tales that would have been taboo twenty ycars earlier. They have developed a high art, on that little magazine with the tremendous circulation, of telling stories that are just short of scandalous, and yet are welcome at the church social." Joun McPartiand, Sex in Our Changing World r77 (I947).

"Incontestably, what the Court means is this: If a book has a substantial tendency to incite lascivious thoughts or to arouse lustful desire, it has a substantial tendency to deprave or corrupt the reader. That tendency is what constitutes obscenity. Lascivious thoughts and lustful desire are depraving and corrupting in themselves." DeVoto, The Decision in the Strange Fratit Case: The Obscenity Statute in Massachusetts, 19 N. Evc. Q. 147, 155-56 (1946).

${ }^{8}$ Lockhart and McClure, Literatture, the Law of Obscenity, and the Constitution, 38 Mins. L. REv. 295, 320 (1954).

${ }^{\circ}$ New Mexico has no law. Florida, Tennessec, West Virginia, and Wisconsin use the single word "obscene." New Hampshire and Georgia have enacted more elaborate definitions in terms of tendencies "to impair, or to corrupt," or to be "offensive to chastity or modesty," ctc. Lockhart and McClure, supra note 8 , at $323 \&$ n. 194,324 .

10 "Few words are as fluid and vague in content as the six deadly adjectives-obscene, lewd, lascivious, filthy, indecent, and disgusting-which are the basis of censorship. No two persons agree on these definitions." Morris L. Ernst and William Seagle, To the Pure . . A Study of Obscenity and THE Censor vii (1928).

${ }^{11}$ Obscene-filthy-foul-profane-impure-unchaste-lewd-licentious-lascivious-libidinous-lustful-lecherous-addicted to lewdness or lust. Merrian-Webster Colleginte Dictionary passim (1946).

${ }^{12}$ Regina v. Hicklin, L.R. 3 Q.B. 360,37 I (1868).

${ }^{13}$ Examples multiply indefinitely. The most recent $I$ have at hand is from Lakewood and Pawtuxet, Rhode Island, where a group of newsdealers has voluntarily removed from the stands any items on a list 
"problem" of obscenity to the problems posed in a series of court proceedings of a rather specialized character, largely concerned with books and most often with books of a special kind-those that fall somewhere between the categories of obvious trash and of unvulnerable classic-whose publishers are sufficiently tenacious or selfconfident to sustain litigation. Since the law offers apparently endless possibilities for reinterpretation, both parties to an obscenity dispute tend to regard it as a critical test-a step, in whichever direction, along the linear scale between total censorship and total liberality. Thus, a lawyer may see in the Ulysses decision" "a great stride forward, possibly a greater stride than in any previous single case," 15 while a congressional committee can see it as "the basis for excuse to print and circulate the filthiest most obscene literature without concurrent literary value to support it, ever known in history." Bo Both share the flattering illusion (for lawyers) that society takes its erotic cues from the bench; but the Ulysses decision, after all, followed a decade of sustained onslaught on social prudery of all kinds, and it was not, in its consequences, the mortal blow to the Hicklin rule that it seemed at the time to be. ${ }^{17}$

The legal defense of literature against legal censorship, concurrently, has had a somewhat confusing effect on debates over obscenity. It has focussed attention on near-irrelevancies, such as the question of artistic merit or the number of equally objectionable elements in Shakespeare and the Bible, and distracted it from the conflicts more importantly at issue- "the fight between the literati and the philistines,"18 as two scholars have put it, for jurisdiction over sexual manners and customs. Both adversaries have frequently found it advantageous, for their respective reasons, to conduct this battle in the courtroom: the censorious, because they see the shock value of bringing before the public selected passages of books that might privately be inoffensive to most literate adults; the defenders of such books, because they see that common sense and most of the law is on their side. The outcome is then in the lap of extremely whimsical deities, and both parties-in defeat-tend to be victimized by the eloquence of their briefs. The literati despairingly conclude that the victories of reason are seldom permanent; the philistines, that "the blackest mud"-the words

of 316 pocket-size book titles and 56 magazines compiled by the Chicago Archdiocesan Council of Catholic Women. Included were works by Hervey Allen, J. D. Salinger, Ernest Hemingway, William Faulkner, John Dos Passos, and Emile Zola. "The Rev. William Gillooly, assistant pastor of the St. Peter's Church and Holy Name Society, said the group wanted to avoid both publicity and the accusation of censorship." Providence (R.I.) Evening Bulletin, March 2, 1955, p. I, col. I. Lockhart and McClure devote ten pages to similar cases of extralegal pressure. Lockhart and McClurc, supra note 8 , at 309-20. A more complete listing may be found in the Bullctins of the Amcrican Book Publishers Council.

It United States v. One Book Called "Ulysses," 2 F. Supp. I82 (S.D.N.Y. I933), aff'd, 72 F.2d 705 (2d Cir. I934).

${ }^{10}$ Morris L. Ernst and Alexander Lindey, The Cessor Marchrs On 21 (x940).

${ }^{10}$ Report of the Select Committce on Current Pornographic Materials, H. R. No. 2510, 82d Cong., 2d Sess. 6 (1952) [hercinafter referred to as the Gatrings Commitee Report].

17 "Though routed, the Hicklin rule was not finally defeated. A battle against it had bcen won, but not the whole war. . . B But even if the war against Hicklin had been won, the problems inherent in any concept of obscenity would still remain." Lockhart and McClure, supra note 8, at 328-29.

${ }^{18} I d$. at 343 . 
are Anthony Comstock's- "is to be found behind the trees on which the sun shines brightest. In that shadow the slime lies thick."10

\section{II}

Comstockery, as Shaw named the disease, ${ }^{20}$ is ever with us. No generation lacks for frightened witnesses to the power of obscenity to corrupt, even where such testimony must necessarily cast a curious light on the individual who offers it. ${ }^{21}$ The cause-and-effect relationship between obscenity and lowered morals, perversion, or crime is simply-for many-an article of faith which no evidence could disturb. Such evidence as there is, regrettably, would not disturb them anyhow since it is likely to be negative and prove mainly that no relationship can be proved-scholarly but superfluous support for Mayor Walker's dictum that no girl was ever ruined by a book. The very idea of literature having a tendency to corrupt can be amply shown to depend on assumptions about the affecting agent, the nature of the effect, the audience affected, and the arbiter of that effect which "are often inconsistent with each other, unprecise and confusing." 22 But the censor marches serenely on.

To those concerned with the inadequacies of the obscenity laws, it has inevitably occurred that a reasonable way out would be to make the demonstration of obscenity contingent on the demonstration of a corrupting effect. One commentator has semiseriously suggested that "[i]t might be an interesting innovation if censorship laws operated only when a plaintiff could prove that he himself had been depraved for lack of proper public safeguards." ${ }^{23}$ Short of this, it might still be possible to require the prosecution of allegedly obscene works to produce at least one witness who would admit to being corrupted by it. Typically, such testimony is offered by the committed proponents of censorship or by law officers. ${ }^{24}$ The cases in which any objective

${ }^{10}$ Anthony Comstock, The Evening Mail (Igo6), quoted in EnNst and Lindex, op. cit. sipra note 15, at 255 .

${ }^{\circ}$ Sec ERNST AND LiNdey, op. cit. supra, note 15 , at 60-61.

21 "No teenager, unless he has ice water in his veins, could look at this material and not be affected by it. A boy gets such a picture, shows it to his girl, they go off to the movies and something is bound to happen." Rev. Daniel Egan, of Graymoor Monastery, Garrison, N. Y., before the Senate Judiciary Subcommittee to Investigate Juvenile Delinquency. See N. Y. Post, May 24, 1955, p. 6, col. 4; N. Y. Times, May 25, 1955, p. I, col. 6; and N. Y. Herald Tribune, May 25, 1955, p. 1, col. 6.

${ }^{22}$ Marie Jahoda and Others, The Impact of Literature; A Psychological Discussion of Some Assumptions in the Censorship Debate i6 (unpublished report from the Rescarch Center for Human Relations, New York University, to the American Book Publishers Council 1954). "The social sciences and psychology are not yct ready to answer the wide range of questions raised in the public debate on harmful books." Ibid.

${ }_{23}$ Watson, Some Effects of Censorship Upon Society, in Protection of Public Morals Through Censorship 76 (New York University School of Law, Social Mcaning of Legal Concepts, No. 5, 1953).

24 In 1949, the dancer, Evelyn "Treasure Chest" West, was arrested on such a complaint in Oklahoma City. "Evelyn was nabbed on a report by $\mathrm{H}$. J. Schmidt and T. J. Wilson, policemen; Mrs. Schmidt, who is a clerk in the county attorney's office, and Miss Vida Campbell, a police clerk. Mrs. Schmidt testificd that she had been excited to 'lewd and lascivious thoughts,' as set out in the statute. Miss Campbell said she considered the dance offensive, but was not excited because she is more than 45 ycars old." The Justice of the Peace pointed out that the persons making the complaint had different standards from those attending nightclubs regularly and that no one was forced to attend against his will; he, thercfore, released Miss West. N. Y. Sunday News, April ro, 1949, p. 95, col. 4. 
effect of the work can be adduced are rare, ${ }^{25}$ however, and there would be grave obstacles, I should think, to requiring that individuals demean themselves in order to incriminate an object. If censorship is wrong in principle, as so many of its opponents believe, then they do ill to grapple with it in terms of tactical trivialities that may win them the engagement but lose the campaign.

Moreover, the so-called "advances" within the law can very quickly be cancelled by retrogressions outside it-a point less appreciated by the literati than by the philistines, who are not so bedazzled by legality. The past few years, in particular, have witnessed an extraordinary comeback among the believers in sex censorship -not simply among its traditional friends, but what can only be called their new intellectual allies. ${ }^{20}$ Even without the latter's help, however, the former have learned to mask their objectives and to seek them without putting the matter of methods to a legal test. ${ }^{27}$ In this they have been encouraged (and considerably instructed) by a committee of the Eighty-second Congress, the Select Committee of the House of Representatives on Current Pornographic Materials, known for short as the Gathings Committee, which tried to discover ways of achieving sex censorship without having to endorse it.

The Committee's report ${ }^{28}$ is a handy compendium of pro-censorship ammunition and a textbook in the techniques of local pressure, yet it obstinately avoids any

${ }^{25}$ The only case I have heard of in which a quantitative test could have been applied was the play, The Captive, with Helen Menken and Basil Rathbone, which dealt with lesbianism and was raided by the police on February 10, 1927. Sales of violets by florists in the Times Square vicinity are said to have risen at first and then fallen off disastrously. "The accent the play placed on violets as a symbol of the third sex for some time kayoed the violet business at florists." Abel Green and Joe LaUrie, JR., Show Biz: From VAude to Video 288 (I950). The Captive (an adaptation by Arthur Hornblow, Jr., of Edouard Bourdet's La Prisonnière) had been passed by a voluntary Citizens Jury of three hundred actors, managers, and playwrights but was included in a crack-down on Mae West's Sex and The Virgin Man. Injunctions were procured permitting the plays to continue, but The Captive closed voluntarily, and the charges were dropped. When Horace Liveright offered to produce The Captive if Gilbert Miller abandoned it, the police thereupon threatened Liveright with the revival of an old obscene-book charge against Maxwell Bodenheim's Replenishing Jessica. See N. Y. Times, Feb. 5, 1955, p. $x$, col. 5; id., Feb. Io, 1955, p. I, col. 7; id., Feb. I1, 1955, p. I, col. I; id., Feb. I5, I955, p. I col. I; id., Feb. I6 1955 p. 1, col. 5; id., Feb. 17, I955, p. I, col. 6; id., Feb. 18, p. 1, col. 6; id., March 9, rg27, p. 27 , col. I.

${ }_{20}$ E.g., Sorokin, The Case Against Sex Freedom, This Week, Jan. 3, 1954, p. 7; and Mead, Sex and Censorship in Contemporary Society, in NJew World Writing, $3 \mathrm{~d}$ Mentor Selection 7 (1953) ("It is an extended argument for some form of legal censorship of pornography," Sheerin, Sex Censorship, 177 The Catholic World, 241 (1953); sec also Sex and Censorship, 58 The CommonWEAL 193 (1953)). The leader of the contemporary attack on comic books is not a backwoods Connecticut neurotic, but an eminent psychiatrist. Frederic Wertham, Seduction of the Innocent (r954); also Wertham, What Parents Don't Know About Comic Books, The Ladies Home Journal, Nov. I953, p. 50 .

${ }^{27}$ And they go on learning. After the defeat in court of the police chief of Youngstown, Ohio, who had tried to apply his own idiosyncratic standards of obscenity, a newspaper columnist in nearby Erie advised his rcaders to use restraint in similar efforts. "Cases in other cities indicate the publishers could hardly lose such a court battle. And with a legal victory behind them, they could then snap their fingers at objections from any local group. . . . The Erie Board of Review of Literature has done a good job in the past year getting rid of a number of publications on a voluntary basis by cooperating with distributors. A series of arrests now, or a hastily enacted city ordinance, would be playing right into the hands of the publishers." Cowden, Erie (Pa.) Dispatch, March 4, 1954, p. 5, col. I.

${ }^{28}$ See note 16, supra. 
overt defense (perish the thought!) of censorship. Aware that federal censorship would be unconstitutional-though its members and witnesses made veiled references to the possibility of on $e^{29}$-the committee instead expressed approval of the "many splendid groups in existence throughout the Nation that devote their efforts assiduously toward eliminating the flood of pornographic material. . ." ${ }^{\prime 30}$ It heard the testimony of such witnesses as the writer Margaret Culkin Banning, who had suggested that in order to avoid the need for censorship by law, the private citizen should "make his protests against printed obscenity felt through his business and professional clubs, his parent-teacher group, the lay association of his church"31-that is, agitate and inflame, form posses, lynch books. The Committee's report, though its reading can hardly be recommended without qualms, merits attention as a fully developed example of Comstockery, genus 1952, at work.

The Gathings Committee seems genuinely not to have desired censorship; it merely desired censorship to be unnecessary. It would rather the whole equivocal business of obscenity were somebody else's problem. Aware that the Post Office is one of the few effective censors left, it asked to have lifted the last pretense of due process from the star-chamber methods by which an opinionated postal inspector can put a publisher out of business. ${ }^{32}$ Aware that no definition of obscenity is satisfactory, it tried to evade the word by diffusing it into a cloud of indefiniteness, recommending that the publishing business eliminate on its own initiative not only the conceivably obscene, but "that proportion of its output which may be classified as 'borderline' or 'objectionable" "-in other words, stop haggling about specific books and throw them all out wherever there is the slightest question. ${ }^{33}$ Aware that sex censorship is, at heart, a social and cultural issue, the Committee reserved its plainest words for a declaration of its social and cultural criteria: "The ascendancy of Puritanism in England promoted a pious reserve in language as in conduct. ... The Victorian era was a time of literary restraint.... It may be that the time has come for the pendulum to swing back again toward decency, a consummation devoutly to be wished. . .."34 Surely nothing could be more candid.

\footnotetext{
${ }^{20}$ Gathings Committee Report passim. $\quad{ }^{30}$ Id. at 29.

${ }^{31}$ Banning, Filth on the Newsstands, Reader's Digest, October 1952, pp. I15, II9, quoted in the Gathings Committee RePort at $135,137$.

${ }^{32}$ Id. at II7-19. This power has since been reduced rather than enlarged. On December 16, 1954, the Federal District Court of Appeals in Washington, D. C., ruled that the Postmaster Gencral could not prevent continued publication of a magazine on the grounds that single issues were obscenc. N. Y. Times, Dec. 17, 1954, p. 22, col. 3. In August 1954, the Los Angeles Post Office seized a limited-edition copy of Aristophanes' Lysistrata mailed from England to a Beverly Hills book dealcr. In March 1955, Edward de Grazia, a Washington attorney, filed in Federal District Court a 24,000 word brief challenging the constitutionality of the "Comstock" Act of 1873 , under which the Post Olfice censors mail. Though the court ruled that there was no constitutional issue, the Post Office released the book before the suit was ended. Mr. de Grazia "suggested that the action reflected the department's unwillingness to test the law ... and announced that his clicnt, backed by the Amcrican Civil Liberties Union, would oppose the government's motion for dismissal. . . " N. Y. Herald Tribune, March 19, 1955, p. 13, col. I. See also N. Y. Herald Tribune, March 6, 1955, p. 27, col. 1; N. Y. Times, March 6, 1955, §I, p. 70, col. 3; and Brief for Appellant, Levinson v. Summerfield, D.D.C. 1955. ${ }^{33}$ Gathings Committe Report 120 . See also id. at 35 .

34 $I d$. at 5 .
} 
One of the many ironies of the obscenity issue is the way in which standards vary, in the eyes of both literati and philistines, among the media. What is permissible in one is forbidden in the next; what would be an outrageous limitation of freedom on one hand is tolerated on the other. The older or more established the medium, generally speaking, the greater the freedom from attack. When it is new, or exploiting a new audience, it must expect to be regarded as a potential outlet for the obscene. Like the Gathings Committee itself, the Victorian prudery that culminated in the Hicklin rule ${ }^{35}$ had been stimulated py the unprecedented extension of literature into previously untouched areas. The njneteenth-century novel, with its exposure of different classes to one another, was aftracting new classes of readers through its serials and lending libraries. A similar impetus was lent to the Gathings Committee by the recent phenomenal development of the pocket-size, paperback book. ${ }^{36}$ The common element in each instanfe is the status rivalry between the lower-middle-class censor, who feels responsible for the morals of the class immediately below him, and the aristocrat, to whom the threat of literature is as nothing compared to the threat of censorship.

In comparison with Victorian times, the reading of books and periodicals by the lower-middle and lower classes (though not entirely free of concern) is today a less emotional issue; experience with mass literacy has ipcreased our reluctance to generalize about literature's "tendencies." The burden of censorship now rests far more heavily on the new "mass media," which chafacteristically-to make matters worse-have a wider and more penetrating impact on the senses than their predecessors. The movies, radio, or television pose problems in censorship so unfamiliar that the upper-class defenders of freedom for the old-fashioned book hesitate to interfere with them. To cope with them at all, we have had to evolve and accept improvised regulations, like the self-policing "codes," which the old media of publishing, press, and stage would regard as unbearably restrictive. No one would dare ask of a newspaper that it observe the same restraints that are constantly being demanded of that current object of fashionable solicitude, the comic-book. ${ }^{37}$

The nature of any censorship, in other words, is aften a function of the anxieties generated by the medium or inherent in the miliey which the medium seeks to serve. At twenty-five to fifty cents, the pocket-size paperbacks are available not only to many adults who had not thought of themselves as book-buyers before, but to adolescents. Despite the overpowering incoherence and banality of its report, the

35 "With this uttcrance sanity was swept away, and Victorian literary prudery and the law made to coincide." ERnst and Seagle, op. cit. stupra note ro, at 130 .

30 "The so-called pocket-size books, which originally started out as chcap reprints of standard works, have largely degenerated into media for the dissemination of artful appeals to sensuality, immorality, filth, perversion, and degeneracy." Gathnos Commettee Report 3.

${ }^{37}$ E.g., "From the lead pages of a New York daily yesterday; N. Y. Phone Tap Center Raided; Sing Sing Squealer Dies in Chair; Bullets Fly in Grudge Fight Outsjde Macy's; Slain Sailor's Pal Found Guilty; Boy Admits Slaying of Girl, 9; Girl Gets 20 Years in Ma's Tub Killing; and Welder Cleared by Jury in $\$ 75,000$ Kidnap Case. In the first five pages of the chropicle, 90 per cent of its space was devoted to crime." Gray N. Y. Post, Feb. 20, 1955, p. 13, col. I. 
Gathings Committee manages to make perfectly clear its desire to establish a connection between the corruption of the young, pornography, and the mass market enjoyed by the seven major paperback publishers then in operation. ${ }^{38}$ It denies to soft-cover books a degree of freedom it must allow to hard-cover ones, on the presumptive grounds that the increasing dissemination of the former constitutes a "menace to the moral structure of the Nation, particularly in the juvenile segment." The implication is that an adult who can afford to pay three dollars and fifty cents for obscenity can take care of himself. It is where the paperback book represents a penetration of "mature" attitudes from the minority bookstore class through to the majority newsstand class that the Committee is alarmed; it would like this process to be either halted or reversed. It sees its real enemies, as Comstock did, among the respectable, the partisans of the liberal enlightenment who insist upon unloosing evil-in the name of mere principle-on susceptible and unprotected youths.

Censorship and obscenity, as such, are not the real issues here-they are only camouflage for issues so embittered they cannot be openly posed. Nor are these, as they are often said to be, merely religious; one of the least sensible crochets of the anti-censorship school lies in attributing to Catholicism attitudes which are equally often, and often more vigorously, espoused by Protestants. ${ }^{40}$ In this respect, the Gathings Committee Report is especially instructive; it can representatively be described-like so much of the contemporary support for censorship-as a counterattack on an assumption of aristocratic invulnerability made by the forces that have been called the "discontented classes," vocal and dissident blocs formed by the intellectually dispossessed in the aftermath of the Roosevelt era. ${ }^{41}$ The Committee comes out against "modern" literature and "liberal" interpretations of the law in virtually the same breath, as though both had equally undermined the Republic. Often, views of this kind are called anti-intellectual, though they are, in many respects, not so much anti-intellectual as anti-chronological-part of a massive, integrated gripe against the passage of time. Clearly their holders are less antagonized by the work of the mind for its own sake than by the dominant literary and artistic style which has made them feel, for more than two decades, that they were esthetically out of fashion. Now that the wheel has turned, turned so far that the excesses of "liberalism" and "modernism" are deplored by those who once committed them, the day has come for revenge. A crusade against pornography, that most helpless of quarries, is made to order.

\footnotetext{
${ }^{38}$ Gathings Committee Rrport 17-20.

${ }^{30}$ Id. at 21 . " . . [ [H]ard-cover books arc limited in circulation and to a large degrec to adults because of their price. . . . Pornographic literature . . . becomes a menace to the morals of the youth of the Nation when it can be purchased at such low prices at any newsstands by adults and juveniles alike." Id. at Ir6.

10 "Our story is concerned with Roman Catholic attitudes, yet the Protestant British censor imposed upon us a much more restricted point of view than the Catholic." Edward Dmytryk, director of The End of the Affair, Coping with British Movie Censorship, N. Y. Hcrald Tribune, April 24, 1955, 54, p. 2, col. 5 . (1955).

${ }^{12}$ See Riesman and Glazer, The Intellectuals and the Discontented Classes, 22 PARTISAN Rev. 47
} 
Thus it is that literature and its advocates find themselves so continually on the defensive, unprotected by the juridical triumphs of the past generation from the smut-hunters of the present one. The open competition among ideas cannot be relied on, where pornography is concerned, as long as no one will openly defend it. ${ }^{42}$ Like Communism or homosexuality, it can be attacked in the secure knowledge that no one will dare occupy its position. It then becomes the focal point for resentments less safe to assert, and everything suspect tends to be lumped together (not surprisingly, numerous citizens, loud in the pursuit of the dirty book, believe it to be somehow connected with the Communists). ${ }^{43}$ Often the "liberal" argument, as a way of touching base with respectability, has allowed that "smur for smut's sake" must be rigorously dealt with-forgetting that this is the only concession the wouldbe censor has ever needed to ask. As long as an exception is made for the indefensible or even the detestable- "Freedom for everybody, except Communists and pornographers"- - then there will be people perfectly prepared to state that you or I are Communists and pornographers, or their dupes, until we prove to the contrary. It is at such times that one remembers why freedom has been said to be indivisible.

\section{III}

An equally serious objection to the treatment of obscenity as a largely legal problem arises from the distorting effect this has on any discussion of sexual morality. Concentration on what is forbidden, according to such arbitrary and variable rules, distracts attention from what is permitted-and from any perspective that might put the two in balance. It would surely seem desirable, where a subject is, by its nature, so delicate, to take into account the extraordinarily wide range of "normal" behavior, the fact that prudes are not the only ones entitled to reticence, and the universal human inability to draw a sharp line between lust and love. An adversary situation over obscenity reduces these factors to their ultimate fragility; it is the native environment of the neurotic, and Comstockery is its natural corollary. It renders the total effects of American sexuality even more ridiculous than they might naturally appear.

Yet, one cannot deal fairly with questions of obscenity without describing the

${ }^{2}$ D. H. Lawrence is no exception. "But even I would censor genuine pornography, rigorously." D. H. Lawrence, Sex Literature and Censorship 74 (I953). The only exception is Henry Miller, Obscenity and the Law of Reflection, Tricolor, Feb. 1945, p. 48, reprinted in HeNRY MILLER, THE Air-Conditioned Nightarare (vol. 2., Reatemeer to Remesiber) 274 (1947).

${ }^{13}$ Congressman Alfred D. Sieminski of New Jerscy expressed the opinion that "distribution of smutty reading and pictorial matter is part of an overall Communist plot to undermine the morals of American youth." Jersey Journal, Dec. 9, 1952, p. 3, col. I. The Director of Public Safety of Newark suggested that "Communists may be responsible for flooding the country with obscene books, pictures, and magazines." N. Y. Post, Dec. I8, 1952, p. 2, col. 3. A Texas attorney, "assailing publications that glorify crime and sex . . . asserted the Communist interest was part of a master plan to weaken the moral fiber of American youth." San Antonio Light, Sept. 5, 1954, p. 10-A, col. 4. In a talk to members of the Newman Club at Tulane, a Sister of the Notre Dame Order said that "Eighty-five per cent of all the crime, horror and sex comic books published in the United States today are subsidized by Red-front organizations." New Orleans Times Picayune, Feb. 18, 1955, p. 2, col. 4. A Massachusetts selectman urged the legislature that comic books should be outlawed "just as the Communist Party was outlawed." Boston Globe, March 22, 1955, p. 3, col. I3. 
context out of which they emerge-the muddle of preoccupations and prohibitions which define, at any given time, the standards each individual must reckon with long before the law does. On these, sex censorship by law has pronounced effects, but they must be regarded as pre-existing-as the raw material of experience in which the law works-rather than as exterior accidents or consequences. Otherwise, consideration in the courtroom of the social effects of obscenity is absurd. If the law cannot recognize the effects which would be found in the absence of a given work of putative obscenity, then it cannot very well determine the effect of that work. However haltingly, in a rough-and-ready fashion, it must operate on some kind of theory of the American sex life-of what it is, or ought to be.

Every disagreement over sex censorship is, by implication-and sometimes overtly, as in the Gathings Committee's endorsement of "pious reserve"4. - a discussion of the sexual state of the nation. The two sides are hardly to be distinguished by their degree of allegiance to the First Amendment or to Romans XIV: 14 as much as by their personal judgment of current standards as either too lax or too severe. Unless all forms of censorship come to be regarded with universal horror, or the law is removed by popular request from the field of obscenity, this state of affairs seems likely to continue for some time to come. That being the case, it devolves on those of us who view the combat from a distance-or from the relative security of other professions-to comment on the materials with a sexual purport which censorship presently lets pass, on the role played by cumulative repression in shaping the American Eros, and on the unintended and ambiguous effects of identifying obscenity with the stimulation of sensual desire. Until these topics can be documented from obiter dicta, however, they will have to stay in the domain of personal opinion which they occupy here.

American attitudes toward sex illustrate the inter-relationship between censorship and provocation in almost clinically pure form; to foreign critics, we offer the most striking example available of a society in which excitation and restraint have the continuous function of intensifying one another. ${ }^{45}$ Every censorship breeds evasion; ${ }^{46}$ it is in our highly developed techniques for evading our own censorship that the American culture fascinates the visitor-or the few local observers sufficiently alert to notice them. To the European eye, we give the impression of making an unwholesome fetish of the female breast, of overwhelming our adolescents with erotic stimuli, and of hiding behind a "puritan façade" the reality of "un des pays sexuellement le

\footnotetext{
4t Sce text accompanying note 34 supra.

45 "L'Amérique cst le pays ou peut se mesurer l'écart le plus saississant qui soit entre la riguer et l'archaïsme des prohibitions sexuelles et l'intensité des appels et des excitations sensuclles." Claude Roy, Clefs Pour L'Axérique 74 (1947). This has not always been the European reaction. Cf. "Les jeunes Américaines des États-Unis sont tellement pénétrées et fortifées d'idées raisonables, que l'amour, cette fleur de la vie, y a déserté la jeunesse. On peut laisser en toute sûretć, à Boston, une jeune fille seule avec un bel etranger, et croire qu'clle ne songe qu'à la dot du futur." STENdali [Manie Henrt BEYLE], De L'ARMOUR 237-38 (x882).

10 "Every censorship produces a technique of evasion as well as a technique of administration." Lasswell, Censorship, 3 ENcyc. Soc. Scr. 290, 294 (1930).
} 
plus libres du monde."' ${ }^{77}$ Confronted with the contrast between our preaching and our practice, we are hard put to refute the thesis propounded a decade ago by Philip Wylie: that the United States is "technically insane in the matter of sex."48

The point need scarcely be labored that the American popular culture is saturated with sexual images, references, symbols, and exhortations; this is a conclusion that both literati and philistines might well agree on, and they might further agree that it reflects a condition of pervasive psychological disease. The difference would be in diagnosis. The censor sees a justification for intensified effort; his opponent sees the result of the censorship now in effect and a warning of disasters to come if more is applied. My own inclination is toward the latter view; and, though I appreciate the obligation to convince those who think differently, I can only fill it by inviting them to examine their own experience from this vantage-point before abandoning it entirely. It is my contention that the symptoms of the American sexual neurosis, if there is such a thing, are the reflected distortions of a moral perspective that diminishes the healthy and accentuates the sick.

To be sure, Americans overemphasize sex partly because they can afford the unique luxury of being able to. If we are the only nation to make love a problem, ${ }^{49}$ we are so in virtue of having emancipated women, reduced the burden of household routines, and offered both sexes an unrestricted vista of domestic bliss and selffulfillment. "Their statesmen are intent on making democracy work," writes a Frenchman of us. "Everybody is trying to make love work, too." W0 We demand a great deal of it. For modern man, sex has been called "the last frontier," to which he looks "for reassurance that he is alive." ciety, it tends to become a consumption good like any other, it is a good whose enjoyment by others remains forever beyond the reach of comparison-an object of limitless potentialities for fantasy and envy.52 Our glamor figures, male and female, whose justification is, in other respects, obscure, serve to maintain an illusion that somewhere, for somebody, sex can be a full-time activity. ${ }^{53}$ The vast majority of us

${ }^{47}$ Roy, op. cit. supra note 45 , at 84 .

48 Philip Write, Generation of Vipers 57 (I942).

10 de Roussy de Sales, Love in America, I61 AtLantic Monthly 645 (1938).

to "The secret of making a success out of democracy and love in their practical applications is to allow for a fairly wide margin of errors, and not to forget that human beings are absolutely unable to submit to a uniform rule for any length of time. But this docs not satisfy a nation that, in spite of its devotion to pragmatism, also belicves in perfection." Ibid.

${ }^{61}$ David Riesman, Reuel Denney, and Nathan Glazer, The Lonely Crowd 154 (1950).

62 "For the making and consumption of love, despitc all the efforts of the mass media, do remain hidden from public view. If someone else has a new Cadillac, the other-directed person knows what that is, and that he can duplicate the experience, more or less. But if someone else has a new lover, he cannot know what that means. . . He is not ambitious to break the quantitative records of the acquisitive sex consumers like Don Juan, but he does not want to miss, day in day out, the qualities of experience he tells himself the others are having." Id. at 155 .

63 The conduct of affairs of the heart in full public view reached an apogee of sorts in 1951 , with the triangular quarrel of two movie stars over a starlet which produced the classic remark by one male-that if the girl married the other, "I'm not going to pay for her Wassermann. . . ." Time, Sept. 24 , 1951, p. 28 . The origins of the altercation are the subject of a learned reference in AnON. [Gersion Legman], The Limerick, i700 Examples, With Notes, Variants, and Index 398 (1953). 
must live on in the knowledge that the indulgences of the glamorous are forbidden; and at times, the heavy Puritan hand descends even on a puzzled unfortunate (like Mr. Jelke, of New York) who was sure that he himself inhabited the charmed circle.

Expecting much of sex, but feeling as individuals that much is denied them, Americans, as a mass, create in the substance of suppressed desire the remarkable symbolic figures that are found here as in no other culture. The existence of "the great American love goddess" ${ }^{4}$ is more often noted than explained. It is apparent that she enjoys high status, that she is attended by elaborate ceremonials, and that the titular embodiment of the divinity (at this writing: Marilyn Monroe) is only the reigning head of a hierarchy of sub-divinities, all of whom possess similar attributes. She is most often a movie star, though her talents as an actress and the merits of the films in which she appears are plainly immaterial. Her primary function is widely understood but rarely mentioned-that is, to serve as the object of autoerotic reverie. ${ }^{55}$ She represents, in brief, the commercial exploitation of the assumption that the American public is composed largely of Peeping Toms. ${ }^{50}$

The assumption would appear to be well founded. It draws sustenance from the approach to sex on similar principles institutionalized by the advertising business. Diverted from literature and the arts, the forces that underlie obscenity or pornography expend themselves in this characteristic American medium. Here sex may be treated as powerful motivation, but only by expressing it in warped and perverted forms-e.g., the women's underwear that is advertised far beyond its proportion of the market, so that we are daily surrounded with pictures of the feminine bosom, leg, and abdomen tightly constrained by clothing (the difference in effect between these and the "bondage photos"57 confiscated by the police seems to me one of degree only). To serve the hunger for the unattainable, we have brought into existence an entire class of women whose profession is catering to voyeurs, not even in the flesh, but through photographs-namely, the models. ${ }^{58}$ At its top are found

5* Winthrop Sargent, Geniuses, Goddesses, and People 196 (1949).

5. "The moral guardians who are prepared to censor all open and plain portrayal of sex must now be made to give their only justification: We prefer that the people shall masturbate. If this preference is open and declared, then the existing forms of censorship are justified." D. H. Lawrence, Pornography AND OBSCENITY 79 (I953).

66 ". . . [S] he is the end-product of symbolist and voyeurist trends in the U.S. that have their roots in the Victorian age, and their high-flung branches in the advertising and entertainment techniques of 1953. . . The danger today, which Miss Monroe tends to symbolize, is that we will come to put a bigher value on these symbolic and voyeurist satisfactions than on real-life relationships." Whitficld, Sex Symbolism and Marilyn Monroe, Why, June 1953, pp. 19, 24. Miss Monroc found her vocation when she was selected as a model by army photographers in a war plant. "The photos got into a lot of papers-and Norma Jcan discovered she enjoyed looking at them, enjoyed it more than anything that had ever happened to her before." Monroe's Lost Years, 953 Screen Annunl.

50 Described by Peter N. Chumbris, associate counsel, before the Senate Judiciary Subcommittec to Investigate Juvenile Delinquency. See N.Y. Herald Tribunc, May 25, 1955, p. 1, col. 6.

o8 "How far this pin-up eroticism, prolonged to saturation point, has already stimulated a mass neurosis is difficult to estimate, but a number of scrious psychiatrists regard the two-dimensional glamour girl, the pictured beauty, the ubiquitous compensation for reality, as the most dangerous will-o'-the-wisp now being pursued by Americans." Robert Junck [Robert Baum], Tommorrow Is Already Here 2 i5 (1954). 
the handful who pose for the fashion magazines and set the pace in cosmetics, posture, style, and aura at the outer reaches of unreal sophistication, where their taut, nerveless langour stands unchallenged-for lack of more full-blooded substitutesas an ideal of the sensual.59

Then, there is the theme of homosexuality, which runs through American popular culture (as well as literature) ${ }^{60}$ like a thread of not-so-innocent deceit. What is deceitful about it is not the conspiratorial existence forced on, accepted by, or darkly attributed to homosexuals. ${ }^{61}$ It is the connivance of the public in something it wishes to be titillated by, but not name-in its approval of novelists whose major theme of hatred for women is rarely mentioned; of comedians whose stock-in-trade is the exhibitionism of spastic, semi-hysterical effeminacy; of Western and detective-story heroes who rigorously spurn their heroines in the search for sadomasochistic purification. All these are not only permitted, but profuse. Not a word of complaint about them comes from the self-appointed custodians of morality, who are far too busily occupied protecting teen-agers from de Maupassant. Censorship, official and unofficial, lets pass into the social mainstream countless images and innuendos that could only be identified-if they were to be identified-as perverse. Of the normal, the lustful thoughts and desires of one sex for the other, it faithfully removes whatever trace it can.

This paradox has been the subject of a book, the most important study of AngloSaxon censorship yet to appear-Gershon Legman's Love and Death. ${ }^{62}$ Mr. Legman's subject is the literary sadism which is intensified by the censorship of sex; his motif is the shameful anomaly of American mores which make love, which is legal in fact, illegal on paper, while murder, which is illegal in fact, is not only legal on paper, but the basis of the greatest publishing successes of all time. To be sure, affection and hatred are opposite poles of human experience, and art necessarily concerns itself with each-the act in which life begins and that in which it ends. The highest skill need not morbidly exaggerate the physical details of either, but neither will be denied it. Deny one only, and the other takes its place. Mr. Legman overpoweringly documents his case that in contemporary America, this is what has substantially occurred.

Though we often speak of sex and sadism together-as two equally regrettable

${ }^{50}$ As always, appearances are deceiving. The current top four-Barbara Mullen, Evelyn Tripp, Jean Patchett, and Dovima Horan-are all married and, according to a photographer, can be hcard to converse as follows: "I don't know what to give my husband for dinner . . . I hope I can make the supermarket before it closes." Barris, My Hour with the Big Four, Photography, May 1955, p. I05.

${ }^{60}$ See Fiedler, Come Back to the Raft Ag'in, Huck Honey!, I5 Partisan Rev. 664 (1948), reprinted in Lestie A. FiedleR, AN ENd to InNocence 142 (1955).

${ }^{01}$ See Towne, Homosexuality in American Culture, American Mercury, Aug. 1951, p. 3; Towne, Sexual Gentlemen's Agreement, 6 Neurotica 23 (I950).

${ }^{0}$ Gershon Legman, Love and Death: A Study in Censorship (1949). The publisher was Mr. Legman himself, after rejection by all firms to whom the manuscript was submitted. This circumstance was subsequently seized upon by the Post Office in order to proceed against the book; but in the interval, without benefit of promotion, it had sold more than 7,000 copies. It is now used as a text in at least one major university. 
qualities in the novels of Mickey Spillane, for example-in actual practice, we tolerate blood and guts in a quantity and concreteness wholly denied to sexual love. ${ }^{63}$ The time-tested formula for the "sexed-up" cover of a paperback book is a near-naked girl with a revolver, and it is curious that critics should comment so often on the nudity and ignore the imminence of death. Within the letter of the law, as in the popular culture, sex and violence tend to be entangled-we label an atomic bomb with the title of a Rita Hayworth movie and call an abbreviated bathing suit a "Bikini"-but in the courts, it is exceptional that the two are prosecuted with equal emphasis. ${ }^{64}$ The typical law against obscenity prohibits it in company with other incitements to crime as well as lust, but we all take for granted the state of general acceptance for printed murdering, whipping, gouging, and wholesale blood-letting which makes half the law unenforceable. ${ }^{65}$

And this is only part of the price we pay for prudery. Is it not too high?

\section{IV}

Needless to say, despite these distractions, society survives. The vanity of lawyers in assuming that the law has a significant effect on sexual habits is matched by the vanity of writers in assuming that literature has a comparable effect. Fortunately, there are other forces at work determining conduct. Almost by definition, such enjoyment of life as there is by the vast majority escapes observation and reporting. Young people, determined to explore the mysteries for themselves, continue to grow up without having been successfully convinced that sex is unclean; nor are they always unwilling to scandalize their elders. ${ }^{86}$ Throughout this society that resolutely

\footnotetext{
${ }^{63}$ See the author's Dames and Death, Harper's, May, 1952, p. 99. Concreteness is, in fact, no longer necessary. Sec the comments by the director-producer of the screen version of a Spillane novel: 'In 'Kiss Me Deadly' the progress of action called for the torturing of a beautiful young girl. The sequence was inescapable. The problem which confronted the screcn play author and myself was how to accomplish this feat and still keep within the bounds of good taste. We finally solved our problem by leaving it to the members of our audience to provide the horror and the repcllent action via their own overactive imaginations and their personal knowledge of the effects of violence. . . The camera focuses first upon the helpless girl and her antagonists. The situation leading up to this moment of torture is well established and is a logical development in the plot. Hands are then layed upon the victim, and from that moment on the suspense is maintained, the violence high-kcyed and the horror spotlighted through sound effects, focusing the camera in a series of elose shots, on her fect, her hands, shadows upon the wall and similar devices. We think we have kept faith with the $60,000,000$ Mickey Spillane readers." Aldrich, You Can't Hang Up the Meat Hook, N.Y. Herald Tribune, Feb. 20, 1955, $\$ 4$, p. 4 , col. I. "If some of our clcaners-up would stop thinking about sex and take a look at this violent crucl stuff, they might yet do us a service." Priestley, in New Statesmen and Nation, quoted in Time, Aug. 9, 1954, p. 62, col. I. Yet, the two continue to be treated as co-equal by most investigators, including Mr. James Bobo, counsel to the Senate Judiciary subcommittee headed by Estes Kefauver (D. Tenn.) which has been investigating "sex and violence" in the movies. "We want to know if the movies make sex and violence pictures because they make more money than others,' he said." N. Y. Post, June 16, 1955, p. 4, col. 2.

"The Gathings Committee unconsciously reflected the same interpretation. It was directed to examine literaturc either containing obscenity or "placing improper emphasis on crime, violence, and corruption" (GATHINGs CoMmitTeE REPORT I), but its attention was concentrated almost entirely on the former.

${ }^{6 E}$ Winters v. New York, 333 U.S. 507 (1948).

${ }^{00}$ E.g., the phenomena known as "panty raids." See N.Y. Herald Tribune, April I7, 1955, p. 60, col. x. This year, in Denver, the girls finally retaliated. N.Y. Post, May 25, 1955, p. 9, col. 1.
} 
pretends to the contrary, there remains a streak of amiable lewdness and bawdry that has nothing to do with literature and breaks through censorship of any kind at the most unexpected times and places. ${ }^{67}$ There is a shudder of outraged horror in each community where a "non-virgin club" is uncovered, but as far as I am aware, these remarkable institutions neither take their inspiration from books nor are in any way discouraged by censorship. ${ }^{68}$ They testify to the extent to which sex can be selfinduced, self-sustaining, and ultimately self-justified.

But even the sophisticated objectors to pornography, who define it as "calculated to stimulate sex feelings independent of another loved and chosen human being," suppress or distort any suggestion that Eros has, in its own right, a civilizing and illuminating potential. They seem to regard its exclusive function as the continuation of the race, and they are somewhat arbitrarily cruel in their strictures on those whose desires fail to be co-ordinated with the propagative process. Mrs. Banning imagines the ads in "sexy magazines" to be directed at "frustrated men, who were too short or too fat or too friendless or too far from home to have a successful sex relationship"; ${ }^{70}$ while Margaret Mead defines the difference between bawdry and pornography as that between the music hall and the "strip tease, where lonely men, driven and haunted, go alone. ..."71 Such views impress me as inadequately informed by an appreciation of sex, not simply as a genetic mechanism, but as one of the avenues through which reality is exposed to us. This blessing has been conferred on mankind impartially and is luckily not within anyone's province to allocate.

There is a sense in which every nation gets the pornography it deserves. If we forbid the writing of erotica to all but those who are willing to break the law, we have no fair complaint if the results are trivial, mean, and inartistic. We are little entitled to the conclusion that the subject matter of sex cannot be tastefully-or even beautifully-treated if we have never tried to treat it so. Least of all can we pride ourselves on our moral stature as a people until we have further progressed beyond the outhouse phase, manifested by the Gathings Committee and its numerous facsimiles, in which a sniggering shame is our characteristic approach to sex. The true obscenities of American life lie in our vicious public consumption of human suffering, in virtually every form and every media. ${ }^{72}$ By comparison, the literature of

\footnotetext{
${ }^{e 7}$ An cmbarrassing instance is said to have confronted the master-af-ceremonies of the radio program "Double or Nothing," on October 15, 1947, when a former Navy nurse described a friend of hers as suggesting that another man "get a good-looking girl like you and take her home and just have a big screwin' party." The next day the sponsor apologized and promised in the future "to maintain the high standard of good, clean radio entertainment which we are endeavoring to bring to you."

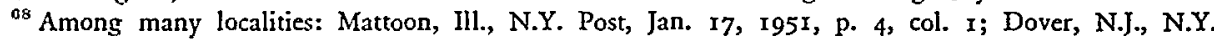
Post, March 7, 1955, p. 3, col. 6.

"Mead, stipra note 26, at I8. Among other examples of the unsophisticated objection is Maisel, The Smut Peddler Is After Your Child, Woman's Home Companion, Nov. I95I, p. 24.

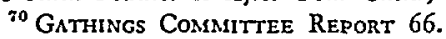

${ }^{71}$ Mead, supra note 26 , at 24 .

${ }^{73}$ The mass media in particular. "Certainly the amount of agony that pours out of the radios and TV sets is greater that at any time in history.... There are half a dozen shows-notably "Welcome Travelers,' 'Strike It Rich,' 'This Is Your Life' and 'On Your Account'-that specialize in misery. . . . Just at the moment 'Welcome Travelers' is featuring child misery, this being considered even more
} 
sexual love would seem to me vastly preferable, but in offering a personal opinion, I hasten to take counsel-while the chance remains-from the words of a distinguished jurist. ${ }^{73}$

There will always be battle in the arena of free opinion; there always has been since Plato thought that Homer should be expurgated and said so. I believe in the constant working of these jaws of natural censorship and am willing to work my own as a part of the process.... I know of no more important time for courageous good taste than when there is not much of it about. Liberty is easier to win than to deserve, and if it is treated as either a license or a vacuum, the police will come or the walls will fall.

poignant and heart-rending than adult misery. . . . However, for sheer assorted agony 'Strike It Rich' is still a few yards out in front of the pack. On any good day on that show you're likely to encounter a ninety-three-year-old gold prospector, blinded by cataracts; a father who wanted to win money for a wheelchair for his nine-year-old daughter, crippled by heart disease; a little girl suffering from cancer with only a few weeks to live; or-strictly for laughs-a man who wanted false teeth because his wife called him Hopalong Cavity. ..." Crosby, N.Y. Herald Tribune, March 30, 1955, p. 25, col. I.

${ }^{73}$ Judge Curtis Bok, statement dated April 24, 1953, for the American Library Association-American Book Publishers Council, Westchester Conference on the Freedom to Read. 